\title{
Chemical Constituents of Buah Makasar [Brucea Javanica (L) Merr] Leaves and Seed Extract
}

\author{
Handa Muliasari ${ }^{1, \star}$, Candra D. Hamdin ${ }^{1}$, Agus Dwi Ananto', and Muhsinul Ihsan ${ }^{2}$ \\ ${ }^{1}$ Study Program of Pharmacy, University of Mataram. Jl. Majapahit No.62 Mataram, Indonesia \\ ${ }^{2}$ Department of Biology, Islamic State University Mataram. Jl. Gajah Mada Mataram, Indonesia \\ *Email: handamuliasari@unram.ac.id
}

Received July 24, 2019; Accepted Agustus 01, 2019

\begin{abstract}
Buah Makasar [Brucea javanica (L) Merr] is one of the local plants in Lombok Island that is traditionally used for diabetic medication. The purpose of this research was to identify the chemical constituents containing in methanol leaves and seed extract of Buah Makasar. The methods used were phytochemical screening for some groups of chemical compounds and GC-MS analysis. The result of phytochemical screening showed that methanol extract of $B$. javanica seed contains alkaloids, terpenoids, and tannin with a high intensity; while the leaves extract contains alkaloids, flavonoids, steroids, tannin, and saponin. The differences of chemical compositions in the leaves and seed extract may give them have different bioactivities. GC-MS analysis showed some fatty acids containing in the seed extract such as stearic acid and palmitic acid.
\end{abstract}

Keywords: Chemical constituents, Extract, Buah Makasar [Brucea javanica (L) Merr], GC-MS

\section{INTRODUCTION}

Buah Makasar (Brucea javanica (L.) Merr) is one of the medicinal plants belonging to the family of Simaroubaceae. It is spread in India, South Asia, and Australia; while in Indonesia Buah Makasar is found in some areas such as Java, Madura and Lombok Island. The seeds and leaves of Buah Makasar are used to treat various diseases, such as fever, hypertension, cancer, malaria, stroke and diabetes [1].

Based on the empirical experience, the seeds of Buah Makasar are used to treat diabetes mellitus [2]. They trust and prove its effect as an antidiabetic by consuming the seeds regularly. The seeds were dried and then the seed skin separated with the seeds. The people consume 510 seeds for one dose to treat diabetes [3].The seeds of Buah Makasar have been reported to contain some compounds such as alkaloids, lignans, terpenoids, glycoside alkaloids, quassinoid glycosides, and quassinoids. Quassinoid is a major compound successfully isolated from the family of Simaroubaceae and is known to have anticancer, antitumor, and antidiabetic activities [4].

The chemical constituents in the leaves and seeds extract of Buah Makasar grown in Lombok Island has not been reported yet. The differences of the growing location of plant will cause the different content of secondary metabolite compounds in plants [5]. Environmental factors such as climate, sunlight, air temperature, atmospheric environments (CO2, O2, and humidity), root environments (soil chemistry and physical properties), and the availability of water in the soil have an influence on secondary metabolic yields of plants [6]. Thus, information of the chemical constituents are important for the development of Buah Makasar as a medicinal materials based on the secondary metabolite compounds contained in the leaves and seeds extract.

This study aims to identify the chemical constituent in the methanol extracts of leaves and seeds of Buah Makasar. The results of this study can be used as the basis for exploring the bioactivity of leaves and seeds extract of Buah Makasar plants, especially those grown in Lombok Island.

\section{EXPERIMENTAL SECTION}

\section{Sample Preparation and Extraction}

Buah Makasar leaves and seeds were collected at Sesaot Village, West Lombok. The leaves and seeds were then air dried and powdered. Leaves and seeds powder was extracted with maceration method using methanol $96 \%$ as solvent. The extract was then evaporated with rotary evaporator to obtain methanol crude extract. 


\section{Phytochemical Screening}

Methanol crude extract of Buah Makasar leaves and seeds were testing for chemical compound containing such as alkaloid, flavonoid, terpenoid, saponin and steroid following the Harborne method [7] and [8],[9],[10]. Analysis of the chemical components in seed extract was also conducted with Gas Chromatography-Mass Spectrometry (GC-MS) QP2010 ULTRA SHIMADZU.

\section{RESULTS AND DISCUSSION}

The extraction of the seed of Buah Makasar was obtaining $7,678 \%$ yield. The leaves and seeds extract were then tested organoleptics and resulted as shown in Table 1. The chemical constituents of Buah Makasar leaves and seeds extract based on phytochemical screening method are shown in Table 2.

Table 1. Organoleptics result of Buah Makasar Leaves and Seeds Extract

\begin{tabular}{ccc}
\hline Parameter & Seed Extract & Leaves Extract \\
\hline Color & Yellow & Dark green \\
Smell & Like peanuts & Agak sepat \\
Tast & Less Bitter & Bitter \\
Texture & Elastic & Soft \\
\hline
\end{tabular}

Table 2. Chemical content of Buah Makasar Leaves and Seeds Extract

\begin{tabular}{ccc}
\hline Compounds & Seed Extract & Leaves Extract \\
\hline Alkaloid & & ++ \\
Flavonoid & ++ & + \\
Terpenoid & +++ & - \\
Steroid & - & ++ \\
Tannin & ++ & +++ \\
Saponin & - & ++ \\
\hline
\end{tabular}

(+) positif (-) negative

Table 3. Major component of Buah Makasar Seeds extract based on GC-MS analysis

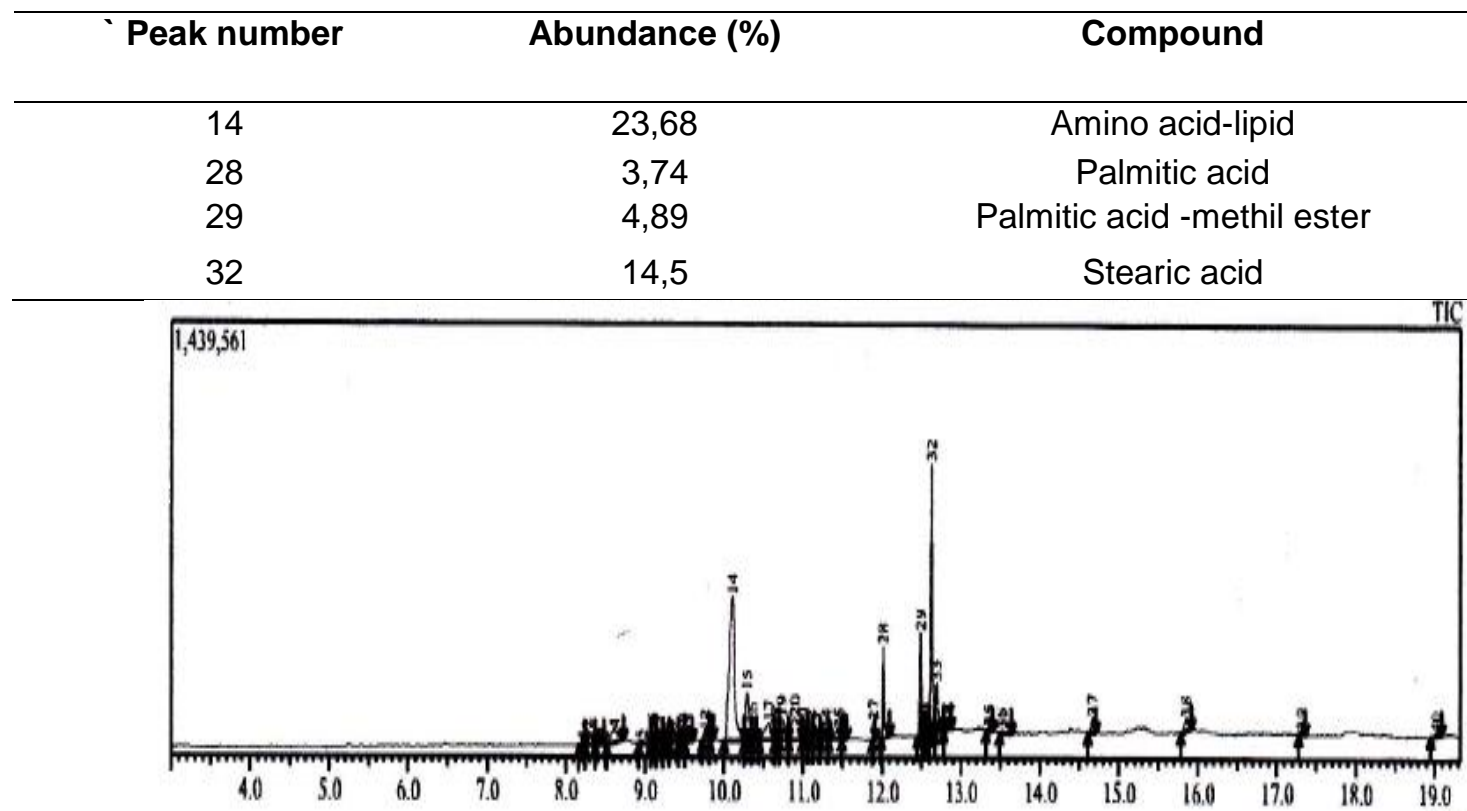

Figure 1. GC-MS spectra of methanol extract of Buah Makasar Leaves

Based on the result of phytochemical screening, methanol extract of Buah Makasar seeds positively identified contain alkaloid, terpenoid, and tannin with high intensity. The 
compounds of flavonoids, steroids, and saponins are not identified. This result is similar with the study conducted by Albat, et al., (2014) which reported that the seeds contained alkaloids, lignans, terpenoids, glycoside alkaloids, quassinoid glycosides, and quassinoids. These compounds are responsible to the activity antidiabetic, antioxidant, and anticancer of Buah Makasar seed extract.

Methanol extract of Buah Makasar leaves was positively identified containing alkaloid group compounds, flavonoids, steroids, tannins and saponins; while terpenoids are identified negatively. The content of terpenoid compounds differ the chemical contents in the extracts of leaves and seeds of Buah Makasar. Another difference is that the alkaloid content is identified less in the leaves extract than the seed extract. The content of flavonoids and saponins in leaves extract are less identified, whereas in the seeds are not identified. The different compounds containing in the leaves and seeds extracts of Buah Makasar allows the bioactivity of leaves extract will be slightly different from the seeds extract. The chemical content and bioactivity of the leaves extract has not been reported, so the exploration of bioactivity of Buah Makasar leaves extract for development as medicine material is still widely open.

The study of chemical content in the seed extract of Buah Makasar continued with analysis using GC-MS, because the seeds contain fatty acids that may also play a role in various biological activities of Buah Makasar seeds. Some primary metabolites of fatty acids and esters are identified with GC-MS (Table 3). The other study of petroleum ether extract of Buah Makasar seeds also identified the presence of fatty acids and esters in the extract [11-14]. Various fatty acid compounds, esters, and other compounds contained in the extracts of Buah Makasar seeds cause the seed extract of makasar fruit has anticancer activity.

\section{CONCLUSION}

Methanol extract of Buah Makasar seeds positively identified contains alkaloid, terpenoid, and tannin compounds with high intensity; while the leaves extract contains alkaloid group compounds, flavonoids, steroids, tannins and saponins. The different compounds containing allows the bioactivity of leaves extracts to be slightly different from the seeds extract of Buah Makasar. The methanol extract of the seeds of Buah Makasar contains several fatty acids with considerable abundance which cause it to have anticancer activity.

\section{REFERENCES}

[1] Ablat, A., Halabi, M. F., Mohamad, J., Hasnan, M. H. H., Hazni, H., Teh, S. H., ... \& Awang, K (2017). Antidiabetic effects of Brucea javanica seeds in type 2 diabetic rats. BMC complementary and alternative medicine, 17(1), 94.

[2] Ablat, A., Mohamad, J., Awang, K., Shilpi, J. A., \& Arya, A. (2014). Evaluation of antidiabetic and antioxidant properties of Brucea javanica seed. The Scientific World Journal, 2014.

[3] Muliasari, H., Hamdin, C. D., Ananto, A. D., \& Ihsan, M. Hypoglycemic Effect of Brucea javanica (L) Merr Leaves and Seed Extract in Alloxan-induced Diabetic Rats. In The 2nd International Conference on Science and Technology 2017, (62)

[4] Ferreira, S. F., Azevedo, S. C. S. F., Vardanega-Peicher, M., Pagadigorria, C. L. S. \& Garcia, R. F. (2013). Efeito antihiperglicêmico de Quassia amara (Simaroubaceae) em ratos normais e diabéticos. Revista Brasileira de Plantas Medicinais, 15(3), 368-372.

[5] Kitagawa, I., Mahmud, T., Simanjuntak, P., Hori, K., Uji, T., \& Shibuya, H. (1994). Indonesian medicinal plants. VIII. Chemical structures of three new triterpenoids, bruceajavanin $A$, dihydrobruceajavanin $A$, and bruceajavanin $B$, and a new alkaloidal glycoside, bruceacanthinoside, from the stems of Brucea javanica (Simaroubaceae). Chemical and pharmaceutical bulletin, 42(7), 1416-1421.

[6] NoorShahida, A., Wong, T. W., \& Choo, C. Y. (2009). Hypoglycemic effect of quassinoids from Brucea javanica (L.) Merr (Simaroubaceae) seeds. Journal of ethnopharmacology, 124(3), 586-591.

[7] Marston, A. (2007). Role of advances in chromatographic techniques in phytochemistry. Phytochemistry, 68(22-24), 2786-2798.

[8] Gothai, S., Ganesan, P., Park, S. Y., Fakurazi, S., Choi, D. K., \& Arulselvan, P. (2016). Natural phyto-bioactive compounds for the treatment of type 2 diabetes: inflammation as a target. Nutrients, 8(8), 461. 
[9] Ciulei, I. 1984. Methodology for Analysis of Vegetable Drugs. Bucharest-Rumania: Chemical Industries Branch DivisionIndustrial Operation UNIDO, pp. 1126.

[10] Kuntorini, E. M., \& Nugroho, L. H. (2010). Structural development and bioactive content of red bulb plant (Eleutherine americana); a traditional medicines for local Kalimantan people. Biodiversitas Journal of Biological Diversity, 11(2).

[11]Su, Z., Huang, H., Li, J., Zhu, Y., Huang, R., \& Qiu, S. X. (2013). Chemical composition and cytotoxic activities of petroleum ether fruit extract of fruits of Brucea javanica (Simarubaceae). Tropical Journal of Pharmaceutical Research, 12(5), 735-742.

[12] Su, B. N., Chang, L. C., Park, E. J., Cuendet, M., Santarsiero, B. D., Mesecar, A. D., ... \&
Kinghorn, A. D. (2002). Bioactive constituents of the seeds of Brucea javanica. Planta medica, 68(08), 730-733.

[13] Pan, L., Chin, Y. W., Chai, H. B., Ninh, T. N., Soejarto, D. D., \& Kinghorn, A. D. (2009). Bioactivity-guided isolation of cytotoxic constituents of Brucea javanica collected in Vietnam. Bioorganic \& medicinal chemistry, 17(6), 2219-2224.

[14] Lau, F. Y., Chui, C. H., Gambari, R., Kok, S. H. L., Kan, K. L., Cheng, G. Y. M., ... \& Chan, A. S. C. (2005). Antiproliferative and apoptosis-inducing activity of Brucea javanica extract on human carcinoma cells. International journal of molecular medicine, 16(6), 1157-1162. 